\title{
Migrações e meio ambiente: desafios contemporâneos e o debate acerca dos "refugiados ambientais"
}

\author{
Migrations and the environment: contemporary challenges and the \\ debate on "environmental refugees"
}

\begin{abstract}
Resumo: $O$ presente artigo tem como problema de pesquisa o seguinte questionamento: quais são as relações intrínsecas entre as mudanças climáticas e as migrações forçadas, especificamente, aliadas à compreensão de um possível refúgio ambiental? A partir dessa proposição, o referido problema se encontra dividido em duas seções de análise: a primeira, destinada a debater os aspectos ambientais que obrigam os seres humanos a migrarem, discorrendo-se acerca da emissão de gases, do degelo, dos compromissos assumidos internacionalmente pelos Estados, entre outros; já a segunda, reserva-se ao direito internacional, especificamente, apresentam-se as discussões sobre o que é um migrante, um deslocado interno e um refugiado. Por fim, as considerações finais indicam que a solução para a migração forçada, por problemas ambientais, não possui assertividade na esfera do sistema internacional atual. Logo, não há a responsabilização compartilhada como aquela pretendida pelas autoras deste estudo.
\end{abstract}

Palavras-chave: Meio-ambiente. Migração. Direito Internacional.

\begin{abstract}
The present article's research problem is the following questioning: what are the relations between climate changing and forced migrations, specifically allied to the understanding of a conceivable environmental refugee? From this question the referred problem is divided in two sections: the first one is to discuss the environmental aspects that force people to migrate, taking into consideration the deforestation, the thawing, the State's responsibility towards international purposes, and others; the second one, is specifically to the international law, bringing to discussion what is a migrant, a internal displacement and a refugee. Lastly, the final considerations demonstrate that the solution to forced migration, in case of climatic problems, does not have assertiveness on the present international system sphere. Thus, there is no shared responsibility as these article's writers wished.
\end{abstract}

Key-words: Environmental; Migration; International Law.

\section{Introdução}

Com o passar das décadas e o consolidar da disciplina, as relações internacionais passaram a contar com os chamados "novos temas". Entre os assuntos em destaque na agenda internacional, inserem-se 
os debates acerca do meio ambiente e das migrações forçadas. No entanto, em uma perspectiva histórica, a novidade estava apenas no foco dado à discussão dos "problemas" advindos dos referidos temas.

Neste artigo, busca-se realizar, através de revisão bibliográfica e de dados do Alto Comissariado das Nações Unidas para os Refugiados (ACNUR), da Organização Internacional para as Migrações (OIM) e do Internal Displacement Monitoring Centre (IDMC), uma análise das relações entre os paradigmas ambientais e a questão das migrações e do refúgio na contemporaneidade.

A partir do avanço científico-tecnológico, do crescimento populacional, da organização socioeconômica, da maior velocidade das transações e comunicações, das lógicas de produção e consumo e de tudo o que isso acarreta, percebe-se uma maior intersecção entre os temas em debate internacionalmente. $\mathrm{O}$ artigo procura ilustrar pontualmente um exemplo dessas intersecções: 0 caso das migrações forçadas por mudanças ambientais ou climáticas na terra natal do migrante.

Nesse contexto, alguns autores e movimentos se empenham pela inclusão da ideia e do termo "refugiado ambiental" no Direito Internacional dos Refugiados, por entenderem que esses migrantes estão fugindo de uma dada situação e estariam sendo forçados, assim como os refugiados, a deixarem seu local de origem, necessitando de uma proteção adequada. No entanto, esse debate se estende, e são levados em consideração diversos outros elementos para além do fato de serem pessoas compelidas a migrar.

Desta maneira, o problema de pesquisa deste estudo está articulado ao seguinte questionamento: quais são as relações intrínsecas entre as mudanças climáticas e as migrações forçadas, especificamente, à compreensão de um possível refúgio ambiental?

Portanto, o artigo se encontra dividido em duas seções principais: a primeira, destinada a debater os aspectos ambientais que obrigam os seres humanos a migrarem, discorre acerca das mudanças climáticas e dos compromissos assumidos internacionalmente pelos Estados; a segunda, reservada para tratar do direito internacional e do que a doutrina disserta sobre o tema, apresenta as discussões sobre o que é um migrante, um deslocado interno e um refugiado, traz a opinião de alguns autores no debate acerca do termo "refugiado ambiental", inclusive indica a visão das autoras. Por fim, as considerações finais retomam os principais pontos e concluem o tema proposto.

\section{MUDANÇAS CLIMÁTICAS E O REGIME INTERNACIONAL SOBRE MEIO AMBIENTE}

A destruição do meio já ocorre há alguns séculos, até mesmo no Brasil, onde, no período colonial, o deslocamento interno era uma necessidade devido ao esgotamento do solo. Nesse sentido, Caio Prado Jr. (2011, p. 140) afirma que os processos destrutivos da primeira fase da ocupação do território eram explicáveis e mesmo insubstituíveis, por conta do limitado conhecimento técnico de agricultura que se tinha. Pela insistência nesses processos, no entanto, já se começavam a sentir seus efeitos, sendo um deles o simples abandono da terra, devido ao seu esgotamento, por anos consecutivos, os quais se tornavam cada vez mais espaçados e faziam a mata desaparecer rapidamente.

Tomando como exemplo o caso do Brasil, o deslocamento interno era uma necessidade devido ao desgaste do solo; entretanto, era o migrante o próprio responsável pela causa de sua migração. 
Naquele contexto de cultivo açucareiro, quem se deslocava era quem esgotava a terra com seu modo de cultivar a cana. Hoje, além de as terras não serem mais tão abundantes como no período colonial, em que facilmente se podia encontrar outro local para reiniciar o cultivo, a necessidade de migrar resulta, em muitos casos, da ação de terceiros, e não por uma prática local.

A fim de retratar essa mudança substancial no grau de intervenção humana sobre o solo e ao próprio meio ambiente, Eduardo Viola e Larissa Basso (2016) elucidam a transição do período Holoceno para o período Antropoceno. Conforme os referidos autores, o Holoceno ${ }^{3}$ foi o intervalo de tempo em que se experimentou significativa estabilidade ambiental, tendo ocorrido desde a última glaciação (findada há cerca de 11 mil anos) até por volta da década de 1970. Já o Antropoceno seria a época geológica vigente, em que a estabilidade assegurada no período Holoceno está sendo paulatinamente perdida devido às ações da própria humanidade, a qual se teria tornado a principal condutora das mudanças do planeta.

Para além da compreensão desse processo pelas ciências naturais, as transformações ocorridas são essenciais, também, para as ciências sociais e humanas no que tange às mudanças implícitas ao entendimento das percepções de ameaça e segurança, inclusive de segurança econômica. A alteração da estabilidade ambiental provoca discussões necessariamente transdisciplinares, que perpassam temas como: disputas por recursos naturais, governança global e vontade política, tratamento de lixo e resíduos, modelos de produção e consumo, noções de soberania, sustentabilidade e migrações e deslocamentos em consequência dos impactos do Antropoceno - enquanto principal objeto deste estudo.

Com o aumento expressivo da população do planeta e do consumo per capita de recursos naturais, a humanidade se tornou protagonista como força de transformação da Terra, consubstanciada no século XXI, quando as condições de escala e cumulatividade foram alcançadas. Portanto, apesar de a Revolução Industrial ter sido o marco que suscitou o Antropoceno, nessa época os impactos da humanidade sobre o mundo ainda não haviam atingido a escala de transformação do meio que se passou a ter a partir do terceiro quarto do século XX. Para Viola e Basso (2016, p. 3),

O início do Antropoceno coincide com a ultrapassagem dos limites planetários. Os limites planetários - mudança do clima, integridade da biosfera, fluxos biogeoquímicos do nitrogênio e do fósforo, diminuição da camada de ozônio, acidificação dos oceanos, uso da água doce, uso dos solos, poluição agregada global por aerossóis e contaminação química (Rockstrom et al., 2009; Steffen et al., 2015) - são limites de resiliência do planeta: se ultrapassados, a estabilidade ambiental é perdida.

Dos limites citados, dois já se encontrariam excedidos: os fluxos biogeoquímicos do nitrogênio e do fósforo (por conta do intenso uso de fertilizantes desde a década de 1950) e a integridade da biosfera (pelo crescimento da população que impactou ecossistemas naturais e outras espécies, até mesmo as extinguindo). Quanto à estabilidade do clima, esta já foi quebrada devido à acumulação

3 Com o término da última glaciação, 11 mil anos atrás, a Terra entrou em uma era de clima mais estável e ameno, que foi chamada de Holoceno e que possibilitou melhores condições de desenvolvimento à humanidade, passando a contar de alguns grupos caçadores-coletores para uma população de 7 bilhões de pessoas. (VIOLA; BASSO, 2016, p. 2). 
de gases de efeito estufa (GEE) na atmosfera. Essa alteração incremental continua em curso, contribuindo para o desequilíbrio ambiental e a ocorrência de desastres. (VIOLA; BASSO, 2016, p. 3).

Conforme relatório de 2018, da Organização Internacional para as Migrações (OIM), somente em 2017, 18,8 milhões de pessoas - em 135 países - deslocaram-se internamente por conta de desastres. (OIM, 2018, p. 44). A migração para outros Estados se torna mais difícil em razão da complexidade de se conseguir permissão de entrada sob tais circunstâncias, mas isso não faz a questão ser menos internacional, já que poderá ser a única opção para muitas comunidades, caso as alterações no clima não sejam mitigadas ou pelo menos reduzidas.

Um possível exemplo de necessidade de transferência de uma população inteira, sem opção de deslocamento interno trata-se do caso Kiribati, em que uma das políticas de Governos anteriores já foi um plano de transferência populacional para as ilhas Fiji, se a previsão de inundação das 33 ilhas que formam o país se confirmasse. (PEIRÓ, 2018). De acordo com a OIM, os Pequenos Estados Insulares em Desenvolvimento (Small Island Developing States, SIDS, na sigla em inglês) continuam sendo desproporcionalmente afetados por riscos naturais, confirmando que esses Estados insulares são os primeiros a sofrer as consequências da mudança climática do planeta, mesmo sendo os responsáveis pelas menores emissões de gases de efeito estufa na atmosfera. (OIM, 2018, p. 44).

Em 2017, os deslocamentos por desastres foram causados principalmente por eventos climáticos extremos, e das 18,8 milhões de pessoas deslocadas por razões ambientais, 8,6 milhões se deslocaram especialmente devido a inundações. Essas 18,8 milhões de pessoas se somaram aos 227,6 milhões de deslocados estimados entre 2008 e 2016, mas enquanto a migração no contexto ambiental ocorre, sobretudo, dentro dos Estados, outros vários migrantes são obrigados a cruzar fronteiras, configurando um percentual de emigrantes (e não de deslocados) que tende a aumentar proporcionalmente à falta de mudanças substanciais nos padrões de produção e consumo.

O relatório da Organização Internacional para as Migrações também esclarece que processos de lento desenvolvimento inicial, como secas ou aumento do nível do mar, afetam cada vez mais a mobilidade das pessoas ao redor do mundo, entretanto, dados sistemáticos de qualidade sobre essas questões não estão disponíveis. (OIM, 2018, p. 44). Sendo assim, a carência de percepção exata do problema é agravada já que os dados globais sobre o movimento transfronteiriço no contexto de desastres são limitados.

Além da elevação do nível do mar e todos os efeitos por isso gerados, as consequências da mudança do clima, responsável por 18 dos 18,8 milhões de deslocados ambientais em 2017 (OIM, 2018, p. 45), convertem-se em eventos climáticos extremos cada vez mais sucessivos. A título de ilustração desses eventos podem-se elencar as secas mais extremas, chuvas mais fortes e concentradas, calor e frio intensos por períodos mais prolongados, sucessão de furacões e tufões, início da liberação de metano aglomerado na tundra siberiana e canadense, choques mais severos entre circulação atmosférica oceânica e terrestre em diversas regiões litorâneas e retração ampla e prolongada do gelo nos verões do oceano Ártico (VIOLA; BASSO, 2016, p. 3).

Diante desses fatores, conforme o Centro de Monitoramento de Deslocamento Interno (Internal Displacement Monitoring Centre, IDMC, na sigla em inglês), desde 2008 (quando se começou a monitorar), o número de deslocados internos (cujo conceito será visto na seção seguinte) por motivos de desastres ambientais supera o número de deslocados internos por razões de conflito 
e violência. Além disso, em todos os anos os deslocamentos estiveram mais associados a questões climatológicas do que a aspectos geofísicos (IDMC database).

Diante dessas questões, encontra-se um cenário doméstico e internacional em que as instituições e os sistemas jurídicos vigentes não estão preparados para lidar com a mudança climática, pois centram-se no raciocínio de causa-efeito de curto prazo (e a instabilidade do clima tem como causas uma gama de atividades humanas diárias, o que torna impensável que a solução seja única) e na provisão de bens privados, não bens comuns (como um meio ambiente equilibrado). A fim de atenuar as mudanças climáticas é fundamental que se reduza a concentração de gases de efeito estufa na atmosfera, primordialmente o carbono.

Para descarbonizar o planeta, mais de uma dezena de atitudes poderiam ser tomadas, entre elas a descarbonização da matriz energética global, diminuindo-se o uso de carvão, não aumentando o uso de petróleo e expandindo-se constantemente o uso de energias renováveis. (VIOLA; BASSO, 2016, p. 4). No entanto, apesar dos avanços tecnológicos que permitem o uso de opções mais sustentáveis e dos avanços no regime internacional do clima, ainda há uma considerável discrepância entre a questão climática e a sua prevalência em meio às características do sistema internacional contemporâneo.

A estrutura do sistema internacional, como existe hoje e já há algum tempo, permite que importantes decisões sejam travadas no Conselho de Segurança das Nações Unidas através do veto; ou que Estados não ratifiquem tratados que não forem de seu interesse, ou, ainda, que simplesmente deixem um compromisso assumido quando da troca de Governo, como poderia ocorrer com os Estados Unidos e o Acordo de Paris ${ }^{4}$, segundo anúncios do atual presidente Donald Trump. Isso ocorre porque, apesar de a mudança climática ter o caráter de negociação de um tema comum global, os Estados são soberanos para interagirem no sistema internacional.

Conforme mencionado na introdução, com a maior quantidade e variedade dos fluxos internacionais (de pessoas, de mercadorias, de informações e de finanças, por exemplo) e "novos atores" (Organizações Não Governamentais, opinião pública, empresas transnacionais, entre outros), "novos temas" se apresentam na agenda de negociações e de debates entre os países, o que implicaria mudanças, também, nas percepções de segurança internacional. Hoje, os estudos de segurança internacional analisam um conjunto muito mais amplo de referências e áreas temáticas do que era o período em que prevalecia a agenda tradicional (paz e segurança), a qual se preocupava quase de forma exclusiva com Estados e poder militar. (BOOTH; WHEELER, 2008, p. 147).

Essa ampliação da agenda significa que a segurança ou insegurança internacional deveria ser entendida primeiramente como um arranjo mais amplo de ameaças, as quais incluem, por exemplo, a pobreza, o meio ambiente, a economia global e a saúde geral, contemplando mais questões (como indivíduos, regiões, a humanidade em si) do que somente Estados soberanos. Diante disso, de acordo com Ken Booth e Nicholas J. Wheeler (2008, p. 147), os estudos de segurança no século

\footnotetext{
4 O Acordo de Paris foi firmado entre 195 Estados partícipes da Convenção-Quadro das Nações Unidas sobre a Mudança do Clima (em inglês, United Nations Framework Convention on Climate Change ou UNFCCC), Convenção que existe desde 1992 e que é resultado da Conferência das Nações Unidas para o Meio Ambiente e o Desenvolvimento (CNUMAD), informalmente conhecida como a Cúpula da Terra, realizada no Rio de Janeiro, em 1992. O Acordo de Paris foi aprovado na $21^{\text {a }}$ Conferência das Partes (COP21), como são chamadas as reuniões periódicas da UNFCCC, em 2015, com a finalidade de reduzir as emissões de gases de efeito estufa. (MINISTÉRIO DO MEIO AMBIENTE).
} 
XXI precisam não apenas de especialistas sobre poder e dissuasão, mas, também, de analistas que entendam de desenvolvimento econômico, de mecanismos de confiança e cooperação e de outras áreas que no contexto da globalização constituem a agenda de segurança internacional.

Com clareza poder-se-iam incluir nessa mesma lista especialistas sobre meio ambiente e mudanças climáticas, já que são temas que impactam o contexto socioeconômico, a necessidade de migrar, os movimentos populacionais, a segurança de fronteira e a segurança energética, ou seja, os principais pontos da geopolítica mundial. Logo, a problemática ambiental como uma matéria de segurança se consolidou nas discussões políticas, na mídia e nas pesquisas no final dos anos 1980.

$\mathrm{Na}$ União Soviética, por exemplo, o acidente do reator nuclear de Chernobyl, em 1986, trouxe a atenção de muitos pensadores soviéticos para o assunto (mas, hoje, a Rússia é uma das potências menos engajadas na discussão) de uma forma que diversos setores em Washington não percebiam na época. Além do acidente, o desmatamento tropical, especialmente no Brasil, e o grande calor no verão de 1988 nos Estados Unidos, quando o fluxo do rio Mississipi foi tão reduzido que a navegação comercial foi interrompida, contribuíram para atrair atenção ao meio ambiente como uma preocupação global e uma dimensão da segurança internacional. (DALBY, 2008, p. 261).

Perante os novos debates nas relações internacionais, a resposta dos Estados foi o desenvolvimento do regime internacional sobre mudanças climáticas. Assim, o marco significativo foi a assinatura da Convenção Quadro das Nações Unidas sobre Mudanças Climáticas (CQNUMC), em 1992, a qual busca soluções para o problema, mas com as obrigações específicas discutidas e decididas em reuniões periódicas, cunhadas "Conferência das Partes (COPs)".

Para este artigo, consideram-se duas COPs como essencialmente importantes: a COP 3, que ocorreu em 1997, em Kyoto, e a COP 21, em Paris. No contexto do Protocolo de Kyoto, os Estados Unidos decidiram não ratificar o documento, declarando que era injusta a competição, em mercados internacionais, com economias em desenvolvimento que não foram obrigadas a reduzir emissões de GEE. No preparo para a COP 21, a tradicional polêmica acerca da obrigatoriedade das imposições continuava, tanto da parte de alguns países desenvolvidos, quanto de países em desenvolvimento.

As economias emergentes, a despeito de aumentarem suas emissões em relação ao total global, permaneciam resistentes à adesão de metas de redução de emissões compulsórias, defendendo que há uma responsabilidade histórica dos Estados desenvolvidos, visto que suas emissões de GEE são maiores e mais antigas. Por outro lado, os Estados Unidos mantinham sua posição de somente aceitar as metas compulsórias para as suas emissões se os países emergentes também tivessem essa obrigação. (VIOLA; BASSO, 2016, p. 7).

A fim de mitigar o problema e as consequências de um meio ambiente em desequilíbrio, entre elas a necessidade de migrar, dado o vínculo entre mudança climática e migração que se mostrou anteriormente, em 2013, os membros da CQNUMC se responsabilizaram por apresentar, até outubro de 2015, suas Contribuições Nacionalmente Determinadas (Intended Nationally Determined Contributions - INDCs, na sigla em inglês). As INDCs precisavam descrever as informações sobre os compromissos que cada Estado membro da Convenção determinaria para si a partir de 2020. Desta forma, em 2015, firmou-se o Acordo de Paris. Entretanto, conforme Viola e Basso (2016, p. 8), “caso o conjunto das INDCs apresentadas for totalmente implementado, a temperatura média 
do planeta subirá $2,7^{\circ} \mathrm{C}$ até 2100 ", ou seja, as determinações que cada país estabeleceu para si ainda permitem que a temperatura média do planeta continue aumentando, e, com ela, as migrações por motivações climáticas.

\section{APROXIMAÇÕES E DISTANCIAMENTOS ENTRE AS MUDANÇAS NO MEIO AMBIENTE, AS MIGRAÇÕES E O REFÚGIO}

Neste capítulo, buscar-se-á descrever os aspectos fundamentais à compreensão acerca das migrações forçadas e, consequentemente, do surgimento dos fluxos de refugiados, de deslocados internos e de migrantes ambientais. Assim, ressalta-se que, ao longo do século XXI, presenciamos a expansão desses movimentos que superam os alarmantes números oriundos da Segunda Guerra Mundial.

Dessa maneira, faz-se veemente a necessidade de um esclarecimento sobre o tema, principalmente para se evitar a xenofobia e possíveis crises sociais, políticas e culturais nos "países em desenvolvimento", presentes no "Sul" global, que estão recepcionando em seus territórios a maior parte desses indivíduos. Afinal, segundo Fábio Konder Comparato, "desde que existem as guerras e as perseguições, reina a discriminação e a intolerância. Dessa circunstância emergem, primordialmente, a situação dos refugiados, como também dos deslocados internos e dos apátridas". (COMPARATO, 2003, p. 231).

Portanto, apresentar-se-ão algumas respostas aos seguintes objetivos específicos deste artigo: verificar a evolução do Direito Internacional dos Refugiados; e identificar as estratégias de cooperação internacional que estão inseridas na condução da proteção a refugiados, bem como a atuação das agências das Nações Unidas quanto ao assunto proposto.

Assim, acredita-se que este é um tema que solapa milhões de vidas a cada ano e que, com a globalização e a promoção de movimentos migratórios dos mais diversos, insta-se aos Estados a responsabilidade de desenvolver políticas que abarquem a presente e cada vez mais crescente chegada de indivíduos oriundos de migrações forçadas. Nesse sentido, entende-se que, no alcance das atribuições das Nações Unidas e das contribuições existentes entre seus países membros, poder-se-ia promover uma perspectiva preventiva quanto à atribuição de uma proteção, coerente à realidade internacional, àqueles que são obrigados a buscar uma alternativa de vida em um novo território.

\section{Os principais marcos normativos e históricos sobre o status de refugiado}

O problema das migrações mistas e, principalmente, com a população refugiada abarca séculos de resistência (por parte de nações que interpretam o refugiado como uma ameaça) e de instabilidade nas esferas econômica, social e política. Dessa maneira, deve-se, primeiramente, atentar para a devida distinção entre migrações voluntárias e migrações forçadas.

Assim, definem-se como migrações voluntárias aquelas que abranjam todos os casos em que a decisão de migrar é tomada livremente pelo indivíduo, sem agente externo e partindo de uma preferência pessoal pela busca de um novo território. Por outro lado, as migrações forçadas são entendidas 
como aquelas em que a vontade do deslocamento é inexistente ou minimizada, consolidando-se nos casos de refúgio, deslocamento interno, apatridia, entre outros. (APOLINÁRIO; JUBILUT, 2010, p. 282).

Por meio de uma pesquisa histórica acerca do refúgio, identifica-se que na Grécia Antiga, em Roma, no Egito e na Mesopotâmia regras claras quanto a esses "status" eram estabelecidas e, em sua maioria, possuíam como característica a perseguição com caráter religioso. Como o refúgio era concedido nos templos, locais sagrados, os perseguidores, como governos e exércitos, não podiam entrar e cooptar esses indivíduos à força. (BARRETO, 2010, p. 12).

Por outro lado, há uma inversão de valores entre o refúgio efetivado na Antiguidade e o atual, afinal, muitos criminosos comuns se valiam da possível proteção ofertada no primeiro período. A partir da criação do sistema diplomático e das embaixadas, o refúgio passa a ser assunto de Estado.

Nesse momento, tal proteção perde sua delimitação religiosa, passando a ser baseada na teoria de extraterritorialidade. Para tanto, cabia ao embaixador concedê-la até os limites de sua embaixada ou residência. Por fim, tal sistema foi substituído pela teoria da territorialidade para se verificar uma maior defesa do refugiado e dos indivíduos que procuravam protegê-lo. (BARRETO, 2010).

Dessa forma, o vínculo do Estado com o indivíduo gera para o primeiro a obrigação de proteção e a consolidação de garantias fundamentais a todos os nacionais de seu Estado-Nação, de acordo com os preceitos da democracia moderna. (PEREIRA, 2014, p. 1). Ao segundo, faz-se mister, em sua conduta como cidadão, atender aos deveres que regem o bom andamento de suas relações em sociedade.

A partir da segunda década do século XX é que se tem a institucionalização jurídica das migrações de indivíduos que sofrem com a violação dos princípios fundamentais e basilares da construção de uma sociedade civil. Ademais, a positivação de instrumentos jurídicos tinha como priori pôr em xeque a impressão de que a comunidade internacional possuía acerca dos refugiados como "elementos indesejados", como pontua Hannah Arendt. (ARENDT, 1989).

Vale lembrar que em meio à formação dos Estados-Nações independentes, esses indivíduos lidavam com a diminuição das possibilidades de acolhida nas mais diversas localidades. A relação direta deste dilema originado se faz entender por meio da seguinte perspectiva de Liliana Jubilut (2007, p. 25): "estando a comunidade internacional dividida em unidades políticas autônomas, e não havendo regras internacionais sobre o tema, cada uma dessas estipulava as regras de entrada em seu território, excluindo grandes contingentes" destituídos de referência ou dinheiro.

Assim, deve-se ressaltar que a instituição da Liga das Nações faz-se fundamental para a sinalização de amparo aos refugiados da época. Em seu Pacto constitutivo (artigo 25), os Estados-membro se comprometiam a cooperar com a Cruz Vermelha que, por sua vez, havia lançado um manifesto para a Liga atuar neste tema como autoridade política supranacional.

Destarte, em outubro de 1921, Fridtjof Nansen foi nomeado o (primeiro) Alto Comissário para os Refugiados Russos. No entanto, a Liga não se deteve a redigir uma definição geral sobre "refugiados", apenas considerava que o que era notavelmente comum entre essas pessoas se tratava da ausência de proteção de seu país de origem (ANDRADE, 2006).

Com o advento da Segunda Guerra Mundial, amplia-se o fluxo das migrações forçadas, pois muitos indivíduos não possuíam proteção estatal. Tem-se, nesse momento, o ponto de partida para a sistematização de uma regulação internacional que abordasse os problemas acima mencionados. 
Antes da formação das Nações Unidas, de fato, em novembro de 1943, as forças aliadas (incluindo-se a União das Repúblicas Socialistas Soviéticas) criaram a Administração das Nações Unidas para o Socorro e Reconstrução (United Nations Relief and Rehabilitation Administration, UNRRA, em inglês) com amplo mandato para assistir às zonas devastas e, especialmente, aos refugiados. Em meados de 1945, essa organização possuía, aproximadamente, 300 equipes exercendo o trabalho humanitário de reparação5 (ACNUR, 2006).

Com o final da guerra, a UNRRA dedicou-se à assistência para a repatriação de 7 milhões de pessoas. A tarefa tornou-se cada vez mais polêmica diante da negativa de repatriação pelas pessoas deslocadas e da oposição entre o bloco ocidental e oriental: o primeiro entendia que cada pessoa deveria ter o direito à liberdade de escolha quanto ao regresso e que esse direito não poderia ferir a garantia de assistência pela organização; já o segundo afirmava que só deveriam receber auxílio as pessoas que retornassem aos seus locais de origem (ACNUR, 2006).

Finalmente, o governo dos Estados Unidos, responsável por 70\% dos fundos destinados à manutenção das operações da UNRRA, negou-se a continuar seu apoio econômico e logístico. Apoiando-se na firme oposição do bloco oriental, decidiu-se negar a ampliação do mandato dessa organização em 1947, como também se instaurou um novo objetivo: criar uma nova organização para os refugiados como uma orientação diferenciada ${ }^{6}$.

No cenário internacional, a Organização das Nações Unidas (ONU) já havia surgido como entidade genuinamente universal disposta a prescrever os ditames para a consolidação da "paz mundial". Dessa feita, em julho de 1947, criou-se a Organização Internacional para Refugiados (OIR) como organismo especializado - não permanente- das Nações Unidas.

Em consonância às definições acerca do status de refugiado, vale lembrar que a Declaração Universal dos Direitos Humanos de 1948 afirma em seu artigo 13 que "todo indivíduo tem direito de deixar qualquer país, inclusive o seu e de retornar a este quando quiser, pois toda a pessoa tem liberdade de circulação". Já em seu artigo 15, assegura que "toda pessoa possui o direito a uma nacionalidade e de não ser privado arbitrariamente da mesma, nem do direito de mudar de nacionalidade" (MILESI, Rosita. 2003, pg. 83).

A Declaração Universal foi responsável por elevar o indivíduo à condição de sujeito de direito na esfera internacional, entretanto, deve-se salientar que como possui "status" de Soft Law aos Estados não há uma previsão punitiva ao descumprimento das recomendações elencadas por ela. Logo, percebe-se que muito das deficiências presentes na esfera internacional fazem referência

\footnotetext{
5 ACNUR. La situación de los refugiados en el mundo 2000. Cincuenta años de acción humanitária. Cap. I Los Orígenes. Icaria Editorial, Espanha: 2006. Disponível em < https://www.acnur.org/fileadmin/Documentos/Publicaciones/2012/8943.pdf>. Acesso em janeiro de 2019. "Em noviembre de 1943, antes incluso del final de la Segunda Guerra Mundial y de la constituición formal de la própria Organización de las Naciones Unidas em Junio de 1945, las fuerzas aliadas (incluída la Unión Soviética) crearon la Administración de las Naciones Unidas de Socorro e Reconstrución (UNRRA). Com el amplio mandato de assistir em el socorro y la reconstrución de las zonas devastadas (...)".

6 ACNUR. La situación de los refugiados en el mundo 2000. Cincuenta años de acción humanitária. Cap. I Los Orígenes. Disponível em <http://www.acnur.org/publicaciones-SRM//cap11.php\#tit11>. Acesso em janeiro de 2019. "Finalmente, el gobierno de los Estados Unidos, que aportaba el 70 por ciento de los fondos de la UNRRA y ejercía em gran parte el liderazgo de la organización, se negó a ampliar el mandato de ésta a partir de 1947 y a darle más apoyo económico y, com la firme oposición de los países del bloque oriental, presionó com fuerza para que se crease una nueva organización para los refugiados com una orientación diferente" (Tradução nossa).
} 
quase que direta a este dilema. Por outro lado, enquanto a Declaração possui caráter meramente orientador e referencial, os pactos que a complementam possibilitam que se estabeleçam obrigatoriedades jurídicas às quais os Estados membros devem velar.

Embora o trabalho da OIR voltava-se à ajuda aos refugiados europeus, esse foi o primeiro organismo internacional que, de forma exaustiva, empenhou-se como meio à solução da problemática pelas seguintes ações: tentativa de repatriação, identificação, registro, proteção legal e política, transporte, reassentamento e reinserção dessas pessoas em sua antiga ou em uma nova região.

A posição diferenciada almejada pelos países como o disposto acima, refere-se à prática de uma política de reassentamento promovida pela OIR em países terceiros, no local de origem ou na localização atual a que esses refugiados ocupavam. Tal posição se verificava na resolução que criou a OIR e delimitou como objetivo: "não será obrigado a regressar a seu país de origem nenhum refugiado ou pessoa deslocada que expresse razões válidas contrárias ao dito regresso" (ACNUR, 2006).

Apesar dos sucessivos Pactos e Declarações de Direitos criados em conformidade com a pioneira Declaração Universal dos Direitos do Homem da ONU de 1948, no âmbito internacional, persistiam violações aos direitos humanos, nas mais variadas formas de opressão contra pessoas e grupos humanos em situação de vulnerabilidade, como minorias étnicas, mulheres, crianças, refugiados e outros. Entretanto, este não é um problema restrito aos espaços subdesenvolvidos do Planeta, como também não ficou restrito apenas àquele período. Nesse sentido, Panikkar (2004, p. 206) observa ainda que "os direitos humanos são igualmente pisoteados no Ocidente e no Oriente, no Norte e no Sul do planeta".

Como o marco temporal da OIR não foi suficiente para vencer o número de refugiados, em 1950, consolidou-se a criação do Alto Comissariado das Nações Unidas para Refugiados (ACNUR). Trata-se de uma organização humanitária, apolítica e social que se estabeleceu sob as seguintes bases: "proteger homens, mulheres e crianças refugiadas e buscar soluções duradouras para que possam reconstruir suas vidas em um ambiente normal" (ACNUR, 2010, p. 15).

Nesse contexto, pode-se dizer que se solidifica o Direito Internacional dos Refugiados visando à defesa daqueles que por "fundado temor de perseguição" veem-se obrigados a se retirar do país de origem ou do qual possuem nacionalidade. Esta seria uma das únicas formas de garantir uma melhor qualidade de vida e a destituição do sentimento de "vida nua", isto é, os homens como objetos de toda forma de exploração e que ainda estão à margem da sociedade.

Portanto, cabem ao ACNUR as seguintes competências: percorrer os caminhos à formação de acordos internacionais em prol dos refugiados; bem como verificar a atuação dos governos quanto aos direitos relativos a esses indivíduos; promover o direito das pessoas que formam a cooperativa engajada no cuidado àqueles já mencionados, incluindo-se nesta a polícia de fronteiras, jornalistas, ONG's, advogados, juízes e funcionários superiores do governo (JASTRAM; ACHIRON, 2001, pgs. 21-27).

Inaugurou-se, nesse mesmo período, a positivação internacional das fontes do Direito Internacional dos Refugiados, por meio da Convenção de 1951 Relativa ao Estatuto dos Refugiados e, mais tarde, com o Protocolo de Nova York 1967 Relativo ao Estatuto dos Refugiados. Estes documentos versam sobre a qualificação do status de refugiado que, à época, estava associado a critérios coletivos.

Nesse sentido, o primeiro qualifica refugiado como aquele 
que em consequência dos acontecimentos ocorridos antes de $1^{\circ}$ de janeiro de 1951 e temendo ser perseguida por motivos de raça, religião, nacionalidade, grupo social ou opiniões políticas, se encontra fora do país de sua nacionalidade e que não pode ou, em virtude desse temor, não quer valer-se da proteção desse país, ou que, se não tem nacionalidade e se encontra fora do país no qual tinha sua residência habitual, em consequência de tais acontecimentos, não pode ou, devido ao referido temor, não quer voltar a ele. (ACNUR, Convenção de 1951 Relativa ao Estatuto dos Refugiados, 1951)

Já o segundo marco normativo, o Protocolo de 1967, age como ferramenta que assegura proteção àqueles que possuem o fundado temor de perseguição para além do contexto espaço-temporal até então positivado em 1951. Por fim, esses documentos são os meios para que qualquer pessoa possa exercer, em caso de necessidade, o direito de procurar e de gozar de refúgio em outro país (ACNUR, 2019C).

Em um primeiro momento, tal reconhecimento era concedido àqueles que provassem serem membros de um determinado grupo perseguido, em função de sua nacionalidade ou etnia, por exemplo, não sendo necessária a comprovação da individualização da perseguição. Na sequência da solidificação do conceito, passou-se a efetivá-lo também por meio de dados de perseguições individuais (JUBILUT, 2007, p. 27).

Nesse sentido, evidencia-se que a fase inicial de universalização do instituto de refúgio ocorreu com a configuração bipolar do mundo, ou seja, em meio à Guerra Fria (embate entre Estados Unidos e União das Repúblicas Socialistas Soviéticas e seus aliados). Nesse momento histórico, a acolhida a pessoas perseguidas e violadas tornou-se um instrumento político interessante como modo de desacreditar o bloco contrário (JUBILUT, 2007, p. 28).

Por outro lado, com a queda do muro de Berlim, expressão para alguns do fim da Guerra Fria, e com o estabelecimento da globalização, permaneceu-se e ainda aumentou-se a proliferação de conflitos étnicos e a violação dos direitos fundamentais. Portanto, acredita-se que novos muros foram sendo construídos, acentuando-se questões de cunho econômico e político no meio interno e externo. Poder-se-ia sugerir um provável reconhecimento de que, de fato, a conjuntura internacional está cada vez mais interconectada com vestígios de sua falta de assertividade no "além fronteiras".

Dessa maneira, deve-se atentar para a divisão de forças que impulsionam a problemática em questão: de um lado, têm-se forças centrífugas que se manifestam no nacionalismo e na eclosão de conflitos étnicos (por exemplo, os casos de Ruanda e da ex-lugoslávia); e, de outro, forças centrípetas que surgem em decorrência da dinâmica dos Estados no sistema internacional e que agravam a situação daquelas populações que possuem menos oportunidades socioeconômicas de proverem os meios para um melhor proveito da vida (JUBILUT, 2007, p.30).

Assim, surgem os migrantes econômicos ou refugiados econômicos e que não se enquadram, de fato, na definição do status promulgada pelas convenções. Além disso, esses indivíduos enfrentam a negativa dos Estados quanto a uma acolhida emergencial, afinal eles podem vir a representar problemas para suas economias domésticas e, dessa maneira, passam a ser considerados indesejáveis. Existem, ainda, os apátridas que são pessoas que nascem sem nacionalidade ou a perdem por determinação do Estado de origem, ficando, portanto, sem proteção de um Estado-Nação (ACNUR, 2019C). 
Para ser um refugiado, por fim, a dogmática jurídica internacional separou o bem fundado temor de perseguição segundo um critério subjetivo e outro objetivo. Quando subjetivo, presume-se o medo do regresso ao Estado de origem ou residência conforme a previsão de um dos preceitos clássicos (raça, religião, grupo social, opinião política ou nacionalidade). Já o critério objetivo é pautado por aquele que deve ser minimamente comprovado pelo solicitante de refúgio (PEREIRA, 2014, p.22).

Entretanto, uma pessoa passa a ter o status de refugiado independentemente de um processo legal de elegibilidade ter sido efetivado pelo governo do país em que se busca abrigo. Na verdade, os governos estabelecem procedimentos de determinação do status a fim de se concretizar a situação jurídica daquela pessoa e/ou os seus direitos e benefícios, segundo os princípios de seu sistema legal (ACNUR, 2019C).

Em situações específicas, o ACNUR pode reconhecer o status de refugiado. Isso acontece de três formas: nos países que não são signatários de quaisquer instrumentos internacionais relativos a refugiados; quando autoridades nacionais pedem à agência que ela assuma essa função; ou quando status definido pelo ACNUR é indispensável para garantir proteção e assistência daquele que apresenta características de bem fundado temor.

Cabe ainda explicitar aqui a diferença entre refúgio e asilo político em que, segundo Flávia Piovesan, o primeiro é um instituto jurídico internacional, que possui alcance universal e o segundo é um instituto jurídico regional, com alcance na região da América Latina. O refúgio é medida essencialmente humanitária, enquanto o asilo é medida essencialmente política. Assim, abarcando o fundado temor de perseguição por motivos religiosos, raciais, de nacionalidade, de grupo social e de opiniões políticas, o refúgio se opõe ao asilo que integra apenas crimes de natureza política. Para o status de refugiado basta o temor acima descrito, enquanto para o de asilado há a necessidade da efetiva perseguição (PIOVESAN, 2006, p. 54).

Por fim, existem ainda as definições de deslocados interno e reassentados. Segundo o ACNUR, as pessoas deslocadas internamente são forçadas a abandonar suas casas pelos mesmos motivos que os refugiados, entretanto elas não atravessaram qualquer fronteira. São exemplos de países com altos fluxos de deslocados internos: Afeganistão, Angola, Azerbaijão, Bósnia e Herzegovina, Colômbia, Croácia, El Salvador, Etiópia, entre outros (ACNUR, 2019b).

Já os reassentados, resumidamente, são os refugiados que não conseguiram encontrar no país em que buscaram proteção garantias que a efetivassem de fato, seja por necessidades específicas dessas pessoas, por situações perigosas que podem ter encontrado ou por questões culturais e de adaptação. Assim, eles são encaminhados a um terceiro país que tem como responsabilidade fornecer proteção jurídica e física a essas pessoas, bem como devem permitir que os refugiados tornem-se cidadãos naturalizados (ACNUR, 2019d).

Em relação aos migrantes ambientais, de maneira geral, há uma proteção oriunda do Direito Internacional dos Direitos Humanos. Portanto, deve-se salientar que o conceito de "refugiados ambientais" não possui um regime de proteção específico positivado. A expressão "refugiado ambiental" foi popularizada por Essam El-Hinnawi, em 1985, pesquisador do PNUMA na época, através de um paper intitulado "Environmental Refugees". (EL-HINNAWI, 1985) 
Também, estes indivíduos são caracterizados como "eco-refugiados" ou "refugiados climáticos". Na perspectiva de se promover uma definição, o Programa das Nações Unidas para o Meio Ambiente (PNUMA) apresenta-os da seguinte forma:

(...) são pessoas que foram obrigadas a abandonar temporária ou definitivamente a zona onde tradicionalmente vivem devido ao visível declínio do ambiente (por razões naturais ou humanas) perturbando a sua existência e/ou a qualidade da mesma de tal maneira que a subsistência dessas pessoas entra em perigo. Por declínio do ambiente se quer dizer, o surgir de uma transformação, tanto no campo físico, químico e/ou biológico do ecossistema que, por conseguinte, fará com que esse meio ambiente temporário ou permanentemente não possa ser utilizado (LISER, 2012, p.o9).

Em se tratando dos prejuízos oriundos da devastação de ambientes biologicamente sustentáveis, segundo Daniel Bell, citado na obra de Giddens (2006, p. 15), "os países se tornam demasiadamente pequenos para solucionarem os problemas grandes, mas também demasiadamente grandes para solucionarem os problemas pequenos". Nesse sentido, evidencia-se que a problemática dos refugiados vem a cada ano se tornando uma grave violação à vida e, portanto, desmonta-se a pretensão de uma humanidade dita civilizada e socialmente correta.

Para evitar todas as tentativas compulsórias de expulsão de um indivíduo requerente de refúgio, a Convenção de 1951 estabeleceu, em seu artigo 33, a normativa de non-refoulement ou não-devolução. Em linhas gerais, determina que "nenhum dos Estados Contratantes expulsará ou rechaçará, de maneira alguma, um refugiado para as fronteiras dos territórios em que a sua vida ou a sua liberdade seja ameaçada (...)" (ACNUR, 1951). Desta maneira, os refugiados ambientais - embora não reconhecidos por proteção específica - deveriam ter o acesso a outros territórios observado como direito à vida, portanto, direito humano básico e indissociável a qualquer "cidadão do mundo".

Por força do princípio Pacta Sunt Servanda (os acordos devem ser cumpridos), em tese, a não devolução tem aplicabilidade para além das regras de direito interno de cada país. Partindo-se dessa premissa, Gustavo Pereira entende que

a proibição da devolução é a primeira garantia conferida ao solicitante de refúgio, assim compreendido pelos instrumentos internacionais. A garantia do não retorno se dá antes mesmo de o Estado analisar o pedido de refúgio do solicitante e, segundo as prerrogativas internacionais, como já foi dito, a falta de documento como passaporte ou identidade, bem como a entrada ilegal do requerente, não podem servir como argumento para a devolução ou deportação, bem como o não reconhecimento do status de refugiado (PEREIRA, 2014, pg. 01).

Em busca de uma solução duradoura, tem-se também inserido nesse contexto a reafirmação de normas mínimas básicas que se encontram no domínio dos direitos humanos, por exemplo, o acesso à justiça, o princípio da não discriminação, a vigência dos direitos civis fundamentais e estabelecidos pela Declaração Universal dos Direitos Humanos de 1948, entre outros. Assim, Trindade (1997, p. 396) pontua que 
a nova estratégia do ACNUR, ao abarcar, além da proteção, também a prevenção e a solução (duradoura ou permanente, voltada à repatriação voluntária, integração local ou reassentamento), contribui a revelar que o respeito aos direitos humanos constitui o melhor meio de prevenção dos problemas dos refugiados. (...) Sempre à luz das necessidades de proteção, a dimensão dos direitos humanos tem igual incidência nas etapas "anterior" de prevenção e "posterior" de solução duradoura.

Segundo Betts (2017, p.52), uma das maneiras atuais de se identificar os refugiados em (e resultantes de) um mundo que se encontra em transformação - socioambiental - seria a partir de uma força maior, ou seja, a ausência de uma escolha racional que não seja unicamente migrar. Nesse sentido, o medo constante de um sério dano físico poderia ser compreendido universalmente a partir de um denominador comum: a saída forçada.

Após o amparo histórico sobre o sistema internacional de proteção a refugiados, presencia-se a falta de assertividade entre os Estados sobre temas sensíveis, de fato, também intrínsecos às mudanças climáticas e ao efeito migratório resultante, como apresentado por este artigo. Portanto, compreende-se que há a necessidade de pontuar as responsabilidades e geri-las de forma preventiva e não reativa no referido sistema.

Um exemplo de programa a se destacar é a Iniciativa Nansen, desenvolvida por Suíça e Noruega. Lançado em outubro de 2012, teve como foco a construção de um consenso entre os Estados para que fosse abordado da melhor forma o deslocamento transfronteiriço ligado às causas ambientais. No entanto, não se obteve grandes êxitos com esta proposta (ACNUR, 2015).

Além disso, reitera-se que a pauta dos "eco-refugiados" deveria ser expandida pelo próprio ACNUR, no sentido deste órgão tentar promover junto aos seus países associados a conscientização deste tipo de migração forçada e, principalmente, dos impactos a todos independentemente de sua posição espaço-geográfica. No entanto, reitera-se que esta medida está associada intrinsecamente a interesses maiores e a pauta não é vista como sendo de "responsabilidades comuns".

\section{CONCLUSÃO}

Voltando-se à presunção de características a serem atribuídas a um refugiado, o Direito Internacional dos Refugiados (DIR) insere-se na esfera do Direito Internacional dos Direitos Humanos (DIDH). Segundo Antônio Augusto Cançado Trindade, é possível que o fenômeno contemporâneo dos deslocamentos em massa tenha contribuído a evidenciar os vínculos existentes entre essas esferas do Direito Internacional. Mais ainda, as necessidades prementes de proteção e assistência humanitária estimularam a interligação entre os Direitos Humanos, o Direito dos Refugiados e o Direito Internacional Humanitário, resultando na ampliação do auxílio às vítimas de diversas violações previstas por esses institutos jurídicos.

No que tange aos "refugiados ambientais" e à mudança climática, não há um sistema internacional positivado que garanta os direitos fundamentais às nações que sofrem com o dilema da migração forçada por prejuízo climático. Também, verifica-se uma dificuldade na forma como os 
atores internacionais lidam com a questão ambiental, justamente por falta de planejamento no longo prazo, já que os problemas da poluição não são sentidos imediatamente.

Embora ocorra a ratificação de acordos referentes à defesa do meio-ambiente, percebe-se que a falta de assertividade vai ao encontro do interesse estratégico de cada Estado, qual seja: prevalecer sua soberania e velar por seu próprio povo e território, no sentido estrito de paz e segurança. Portanto, salienta-se que o "refúgio ambiental" se encontra no mesmo estigma da proteção ao meio ambiente: não há o compartilhamento de responsabilidades comuns.

Para a mudança deste paradigma, verifica-se que a pauta de migrações e meio-ambiente precisa ser impulsionada para além do meio acadêmico, no sentido de imprimir o resultado de seus estudos em tentativas plurais de políticas públicas orientadas ao futuro das nações.

\section{REFERÊNCIAS}

ACNUR. Breve histórico do Acnur. Disponível em: https://www.acnur.org/historia-del-acnur.html. Acesso em: jan. 2019 (a). https://doi.org/10.2307/j.ctvghvtdx.11

ACNUR. Convenção Relativa ao Estatuto dos Refugiados (1951). Disponível em: http://www.acnur. org/t3/fileadmin/Documentos/portugues/BDL/Convencao_relativa_ao_Estatuto_dos_Refugiados. pdf?view=1. Acesso em: jan. 2019. https://doi.org/10.21527/2317-5389.2018.12.248-263

ACNUR. Deslocados internos. Disponível em: https://www.acnur.org/portugues/quem-ajudamos/ deslocados-internos/. Acesso em: jan. 2019(b).

ACNUR. El ACNUR se compromete con la Iniciativa Nansen sobre cambio climático y desastres naturales y lanza un nuevo informe sobre su trabajo en esta área. Publicado em 2015. Disponível em: https://www.acnur.org/noticias/press/2015/10/5b7e71251f/el-acnur-se-compromete-con-la-iniciativa-nansen-sobre-cambio-climatico-y-desastres-naturales-y-lanza-un-nuevo-informe-sobre-su-trabajo-en-esta-area.html. Acesso em: 10 jun. 2019. https://doi.org/10.18356/4cccd34f-es

ACNUR. La situación de los refugiados en el mundo 2000: cincuenta años de acción humanitária. Espanha: Icaria Editorial, 2006. Disponível em: https://www.acnur.org/fileadmin/Documentos/ Publicaciones/2012/8943.pdf. Acesso em: jan. 2019.

ACNUR. Perguntas e Respostas. Disponível em: https://www.acnur.org/portugues/dados-sobre-refugio/perguntas-e-respostas/. Acesso em: jan. 2019(c). https://doi.org/10.11606/t.8.2019. tde-19032019-135620

ACNUR. Refúgio no Brasil: A proteção brasileira aos refugiados e seu impacto nas Américas. Brasília/ DF: 2010. P. 15. Disponível em: https://www.acnur.org/portugues/wp-content/uploads/2018/02/ Ref\%C3\%BAgio-no-Brasil_A-prote\%C3\%A7\%C3\%A30-brasileira-aos-refugiados-e-seu-impactonas-Am\%C3\%Agricas-2010.pdf. Acesso em: jan. 2019. https://doi.org/10.31692/2526-7701.iicointerpdvagro.2017.00100

ACNUR. Soluções Duradouras: reassentamento. Disponível em https://www.acnur.org/portugues/ solucoes-duradouras/. Acesso em: jan. 2019 (d).

ANDRADE, José Henrique Fischel. A política de proteção a refugiados da Organização das Nações Unidas: sua gênese no período pós-guerra (1946-1952). Tese (Doutorado) - Instituto de Relações Internacionais, Universidade de Brasília, 2006. Disponível em: http://repositorio.unb.br/bitstre- 
am/10482/3726/1/Tese\%20-Jose\%20Henrique\%2oFischel\%2ode\%20Andrade.pdf. Acesso em: 6 jun 2019. https://doi.org/10.5007/1806-5023.2017v14n1p46

APOLINÁRIO, Silvia Menicucci. O. S.; JUBILUT, Liliana Lyra. A necessidade de proteção internacional no âmbito da migração. Revista Direito GV, São Paulo, 2010, v. 6, n. 1, p. 275-294, 2010. https://doi. org/10.1590/s1808-24322010000100013

ARENDT, H. Origens do totalitarismo: anti-semitismo, imperialismo e totalitarismo. São Paulo, Companhia das Letras, 1989.

BARRETO, Luiz Paulo Teles Ferreira. Refúgio no Brasil: A proteção Brasileira aos Refugiados e seu impacto nas Américas. Cap I. A Lei Brasileira de Refúgio- Sua História, p. 12. Brasília: ACNUR, Ministério da Justiça, 2010.

BETTS, Alexander; COLLIER, Paul. Refuge: Transforming a broken refugee system. United Kingdom: Penguin Random House (UK), 2017. https://doi.org/10.3917/pro.364.0106

BOOTH, Ken; WHEELER, Nicholas J. Uncertainty. In: WILLIAMS, Paul D. Security studies. Abingdon: Routledge, 2008. p. 133-150.

COMPARATO, Fábio Konder. A afirmação histórica dos direitos humanos. São Paulo: Saraiva, 2003. DALBY; Simon. Environmental Change. In: WILLIAMS, Paul D. Security studies. Abingdon: Routledge, 2008. p. 260-273.

EL-HINNAWI, Essam. Environmental Refugees. Nairobi: UNEP, 1985. Disponível em: https://digitallibrary.un.org/record/121267. Acesso em: 12 jan. 2019

GIDDENS, Anthony. 0 mundo na era da globalização. Lisboa: Presença, 2006. p.15-18.

INTERNAL DISPLACEMENT MONITORING CENTRE. Disponível em: http://www.internal-displacement.org/database/displacement-data. Acesso em: 7 jan. 2019.

JASTRAM, Kate; ACHIRON, Marilyn. Guia sobre o direito internacional relativo aos refugiados 2001. [S. l. : s. n.], 2001. p. 21-27.

JUBILUT, Liliana Lyra. O Direito Internacional dos Refugiados e sua Aplicação no Ordenamento Jurídico Brasileiro. São Paulo: Método, 2007.

LISER. Refugiados Ambientais. Living Space for Enviromental Refugees. UNICEF, 2012. Disponível em: https://www.unicef.org/socialpolicy/files/Environmentally_displaces_people.pdf. Acesso em: jan. 2019.

MILESI, Rosita. Refugiados Realidade e Perspectivas. Brasília: Loyola, 2003.

MINISTÉRIO DO MEIO AMBIENTE. Acordo de Paris. Brasília: Ministério do Meio Ambiente, [201-]. Disponível em: http://www.mma.gov.br/clima/convencao-das-nacoes-unidas/acordo-de-paris. Acesso em: 3 jan. 2019. https://doi.org/10.5380/dma.v47io.62444

ORGANIZAÇÃO INTERNACIONAL PARA AS MIGRAÇÕES. Global Migration Indicators. Berlim: Global Migration Data Analysis Centre (GMDAC), 2018. p. 44-45.

PANIKKAR, R. Seria a noção de direitos humanos uma concepção universal? In: BALDI, C. A. (org.). Direitos humanos na sociedade cosmopolita. Rio de Janeiro: Renovar, 2004. https://doi. org/10.24824/978854442035.5

PEIRÓ, Patrícia. O primeiro país que o mar vai engolir com a mudança climática. El País, Madri, 20 set. 2018. Disponível em: https://brasil.elpais.com/brasil/2018/o9/14/internacional/1536940957_042749. html. Acesso em: 3 jan. 2019 
PEREIRA, Gustavo Oliveira de Lima. Direitos Humanos e Hospitalidade: a proteção internacional para apátridas e refugiados. São Paulo: Editora Atlas, 2014.

PIOVESAN, Flávia. O direito de asilo e a proteção internacional dos refugiados. In : RODRIGUES, Viviane Mozine (org.). Direitos humanos e refugiados. Vila Velha: UVV, 2006. p. 54-95. https:// doi.org/10.24824/978854440818.6

PRADO JR.; Caio. Formação do Brasil Contemporâneo. 1. ed. São Paulo: Companhia das Letras, 2011.

RAMOS, Erika P. Refugiados ambientais: em busca de reconhecimento pelo direito internacional. Tese (Doutorado em Direito) - Faculdade de Direito, USP, São Paulo, 2011. https://doi.org/10.11606/t.2.2011. tde-10082012-162021

VIOLA, Eduardo; BASSO, Larissa. O sistema internacional no antropoceno. Revista Brasileira de Ciências Sociais, São Paulo, v. 31, n. 92, p. 1-18, 2016 . https://doi.org/10.17666/319201/2016

TRINDADE, Antônio Augusto Cançado. Capítulo VIII: As três vertentes da proteção internacional da pessoa humana - aproximação ou convergências entre os Direitos Humanos, o Direito Humanitário e o Direito dos Refugiados. In: TRINDADE, Antônio Augusto Cançado. Tratado de Direito Internacional dos Direitos Humanos. Porto Alegre: Sergio Antonio Fabris Editor, 1997. p. 396-398. https://doi. org/10.1017/s0250569x00017532

Recebido: $15 / 02 / 2019$

Aceito: 21/05/2019

\section{Biografia do Autor}

\section{Bruna Gorgen Zeca}

Bacharel em Relações Internacionais. Mestranda em História pela Pontifícia Universidade Católica do Rio Grande do Sul (PUCRS) e bolsista do CNPq. Em 2014, foi bolsista do Santander para período de estudos na Peking University (China). Tem interesse nas áreas de Política Externa Brasileira, História das Relações Internacionais e estudos geopolíticos envolvendo o meio ambiente. ORCID: http://orcid.org/0000-0002-8115-7813; EMAIL: brunagorgen@hotmail.com

Instituição: Pontifícia Universidade Católica do Rio Grande do Sul.

Localização: Av. Ipiranga, 6681 -Partenon - Porto Alegre/RS

\section{Carolina Cunha César}

Especializanda em Estratégia e Relações Internacionais Contemporâneas pela Universidade Federal do Rio Grande do Sul (2018-2019). Graduada em Relações Internacionais pela Universidade do Vale do Rio dos Sinos (2015) Ao longo da graduação, implementou o Centro Acadêmico de Relações Internacionais (CARI) da Universidade do Vale do Rio dos Sinos (UNISINOS). Tem experiência na área de Ciência Política, com ênfase em Relações Internacionais, Bilaterais e Multilaterais. Possui interesse na área de Segurança Internacional e no Direito Internacional, especificamente, no Direito Internacional dos Refugiados e Migrações. Como experiência profissional, foi assessora técnica na 
administração pública estadual, na Secretaria Estadual do Planejamento, Governança e Gestão (SPGG). Atualmente,trabalha na Associação Antônio Vieira (ASAV) no Programa de Reassentamento Solidário promovido por esta instituição em parceria com a Organização das Nações Unidas (ONU), especificamente com o Alto Comissariado das Nações Unidas para Refugiados (ACNUR). Também, atua como articulista voluntária no CEIRI NEWSPAPER (https://ceiri.news/) tendo como objeto de estudo temas correlatos à América Latina. ORCID: http://orcid.org/0000-0001-5049-0149; EMAIL: carolina_cunha_cesar@hotmail.com

Instituição: Universidade Federal do Rio Grande do Sul.

Localização: Av. Paulo Gama, 110 - Farroupilha, Porto Alegre - RS, 90040-060. 